\title{
STEAM GASIFICATION OF OAT WITH CONVERSION OF TARS ON CLAY CATALYST AND GAS CLEANING BY CONDENSATION OF STEAM
}

\author{
ZGAZOWANIE PARĄ OWSA Z KONWERSJĄ SMÓŁ NA KATALIZATORZE \\ GLINIANYM I OCZYSZCZANIE GAZU PRZEZ KONDENSACJĘ PARY
}

\begin{abstract}
Gasification of oat grains with steam at normal pressure has been performed in a laboratory scale. Experiments were carried out in a vertical quartz reactor, with a steady flow of the steam and immediate tars conversion at $900^{\circ} \mathrm{C}$ on the catalytic bed prepared from local clay with simple additives. Condensation of steam excess enabled essential elimination of non-volatile components of the gas stream. Condensates were analyzed with GC-MS. The highest level of organic compounds was detected in experiment with non-catalytic bed of small quartz pieces $(90.2 \mathrm{mg} / 15 \mathrm{~g}$ of oat grains) and successful decreased by $86 \%$ for original clay without additives (precursors), $94 \%$ for clay with magnesium precursor, $97 \%$ with iron and more than $99 \%$ with calcium one.
\end{abstract}

Keywords: biomass, oat, steam gasification, tar elimination, tar

\section{Introduction}

Fundamentals of biomass pyrolysis as well as technologies of gasification and gas cleaning have been reviewed many times, for example by Van de Velden et al [1], Baruah and Baruah [2], Sharma et al [3], Heidenreich and Foscolo [4], Ruiz et al [5], Abdoulmoumine et al [6], Shen and Yoshikawa [7], Chan and Tanksale [8], Xu et al [9], Lan et al [10]. Quality of biomass syngas is crucial for the syngas applications, particularly in small or medium scale units. Moreover, high temperature, close to equilibrium, steam gasification is attractive due to enrichment of the product gas in hydrogen. Gasification with steam enables elimination of air nitrogen, but such process is endothermic. This problem may be solved by enrichment of steam with oxygen (eg Meng et al [11]) or, for circulating bed gasifier, by combustion of not gasified carbonized residue in a separate furnace followed by recycling hot bed material to gasification unit ( $e g$ Wilk and Hofbauer [12]). The heat pipes system was also investigated for steam gasification, $e g$ by Gallmetzer

\footnotetext{
${ }^{1}$ Faculty of Chemistry, Wroclaw University of Technology, ul. Wybrzeże Wyspiańskiego 27, 50-370 Wrocław, Poland, phone +48 713202449

${ }^{2}$ Faculty of Environmental Engineering, Wroclaw University of Technology, ul. Wybrzeże Wyspiańskiego 27 , 50-370 Wrocław, Poland

*Corresponding author: monika.zablocka-malicka@pwr.edu.pl
} 
et al [13] or Panopoulos et al [14]. Generally, steam in gasification process is usually considered as a reagent for water gas and water gas shift reactions. In experiments described in this paper, we decided to use a considerable excess of steam, not only for better conversion of biomass but principally for rough elimination of low volatile products of gasification during condensation of the steam excess. Condensation of unreacted steam enables separation, together with aqueous condensate, water-soluble and non-soluble fractions (tars, oils, inorganic particles and compounds) and their re-direction to the reactor (in non-laboratory arrangements). To support conversion, we applied catalysts prepared on the basis of inexpensive local material (clay). Catalytic substances (precursors) have been also extensively discussed in literature, eg Shen and Yoshikawa [7], Xu et al [15], Nordgreen et al [16], Chan and Tanksale [8] or Nzihou et al [17]. We chose from many options three substances, commonly available and low-cost: calcium carbonate, magnesium carbonate and iron oxide. The process was performed under undiluted steam at atmospheric pressure in a laboratory scale, with samples of oat grains from local crops.

Intention of experiments was evaluation of efficiency of non-commercial, simple catalysts in elimination of tars and oils which condense with steam excess during allothermal gasification of oats grains. Composition of the final product gas was not separately analyzed. It was broadly discussed in literature (eg de Lasa et al [18]) and for longer reaction times may be calculated assuming thermodynamic equilibrium of the system. The later method was applied in this paper (it standardizes such evaluation and eliminates disadvantages of the gas analysis in experiments in a small, laboratory scale). However, characteristic details of the oat pyrolysis/gasification were taken into account in these calculations.

\section{Materials and methods}

\section{Experimental section}

\section{Oat samples}

Oat grains were preliminary dried in the laboratory for several months in an open container at ambient temperature. Their proximate analysis, gross calorific value (GCV) and net calorific value (NCV) were determined according to ISO standards. Contents of carbon, hydrogen, nitrogen and sulfur were determined by CHNS VarioEL analyzer (Elementar Analysensysteme $\mathrm{GmbH}$ ) and oxygen content was calculated by difference. Metals concentration was determined by AAS/ICP from microwave mineralized samples. Concentration of chlorine was determined by IC according to PN-EN ISO 10304-1:2001 standard. Results of analysis are given in Table 1.

Table 1

Proximate analysis and elemental composition of oat grains

\begin{tabular}{|l|c|}
\hline & Oat grains \\
\hline Proximate analysis [wt.\%] & 8.01 \\
Moisture $\left(M_{a d}\right)$ & 2.46 \\
Ash content $\left(A_{a d}\right)$ & 82.9 \\
Volatile matter content $\left(V_{d a f}\right)$ & 15.0 \\
Fixed carbon $\left(C_{f i x, a d}\right)$ & 17.4 \\
Gross calorific value $\left(G C V_{a d}\right)[\mathrm{MJ} / \mathrm{kg}]$ & 15.8 \\
Net calorific value $\left(N C V_{a d}\right)[\mathrm{MJ} / \mathrm{kg}]$ & \\
\hline
\end{tabular}




\begin{tabular}{|c|c|}
\hline & Oat grains \\
\hline Ultimate analysis [wt.\%] & 53.6 \\
$\mathrm{C}^{\text {daf }}$ & 7.06 \\
$\mathrm{H}^{\text {daf }}$ & 2.06 \\
$\mathrm{~N}^{\text {daf }}$ & 0.19 \\
$\mathrm{~S}^{\text {daf }}$ & 37.1 \\
$\mathrm{O}_{\text {(diff }}$ & \\
\hline Content of other elements [mg/kg] on dry basis & 50.7 \\
$\mathrm{Na}$ & 4950 \\
$\mathrm{~K}$ & 2660 \\
$\mathrm{P}$ & 592 \\
$\mathrm{Cl}$ & 3100 \\
$\mathrm{Si}$ & 109 \\
$\mathrm{Al}$ & 1500 \\
$\mathrm{Ca}$ & 69.8 \\
$\mathrm{Mn}$ & 560 \\
$\mathrm{Fe}$ & 1270 \\
$\mathrm{Mg}$ & 20.2 \\
$\mathrm{Zn}$ & 9.10 \\
$\mathrm{Cu}$ & 0.513 \\
$\mathrm{As}$ & \\
\hline ad - air dried, daf - dry ash free & \\
\hline
\end{tabular}

\section{Catalyst}

Equilibration of gaseous phase was promoted by catalytic granules with diameter of Natural aluminosilicate was gained from small, local deposit in the south-west Poland. Original raw clay was dried at ambient temperature and pulverized in a laboratory mill. Fraction below $0.25 \mathrm{~mm}$ was used for formation of wet granules followed by drying and calcination (Fig. 1).

a)

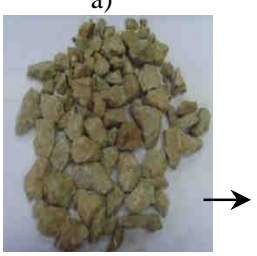

b)

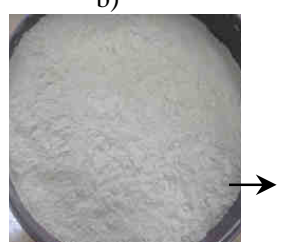

c)

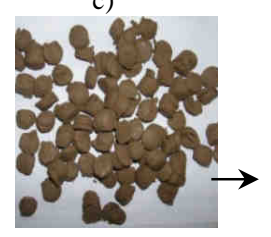

d)

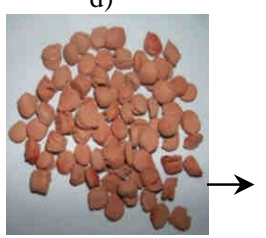

e)

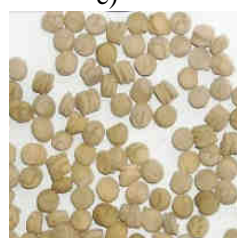

Fig. 1. a) Original clay from local deposit, b) powder fraction of the dried clay, $<0.25 \mathrm{~mm}$, c) pellets before thermal treatment (AS type), d) calcined pellets, e) pellets after gasification experiment

This simple procedure of preparation was similar to the one described by Miao at al [19]. The clay and precursor powders (fractions below $0.25 \mathrm{~mm}$ ) were mixed with polyethylene glycol, PEG (poly(oxyethylene), ROTH Type 600 (liquid), average molar mass: 570-630 g/mol, CAS 25322-68-3) at proportions given in Table 2. Precursors were: calcium carbonate, $\mathrm{CaCO}_{3}$ (CAS 471-34-1 (p.a. POCH S.A. Poland), magnesium carbonate hydroxide, $4 \mathrm{MgCO}_{3} \cdot \mathrm{Mg}(\mathrm{OH})_{2} \cdot 5 \mathrm{H}_{2} \mathrm{O}$, CAS $12125-28-9$ (p.a. POCH S.A. Poland) and iron(III) oxide, $\mathrm{Fe}_{2} \mathrm{O}_{3}$, CAS 1309-37-1 (pure POCH S.A. Poland). Mixtures were homogenized and pellets of $10 \mathrm{~mm}$ diameter and 3-4 $\mathrm{mm}$ thick were formed. Pellets were dried at $120^{\circ} \mathrm{C}$ for 24 hours. Calcination of pellets was performed in Nabertherm $\mathrm{GmbH} \mathrm{N}$ 150 furnace with the following procedure: heating from ambient temperature to $950^{\circ} \mathrm{C}$ for 
9 hours, heating for 3 hours at $950^{\circ} \mathrm{C}$ and free cooling overnight to $\sim 100^{\circ} \mathrm{C}$. Weight losses during drying and calcination are also given in Table 2. The following abbreviations for prepared catalyst samples were applied below in the text: AS - aluminosilicate without additives; $\mathrm{AS} / \mathrm{Ca}$ - clay $+\mathrm{CaCO}_{3} ; \mathrm{AS} / \mathrm{Mg}-$ clay $+4 \mathrm{MgCO}_{3} \cdot \mathrm{Mg}(\mathrm{OH})_{2} \cdot 5 \mathrm{H}_{2} \mathrm{O}$; $\mathrm{AS} / \mathrm{Fe}-$ clay $+\mathrm{Fe}_{2} \mathrm{O}_{3}$.

Table 2

Composition and weight losses [wt.\%] of pellets during preparation of catalysts (details in the text).

PEG - poly(oxyethylene)

\begin{tabular}{|c|c|c|c|c|c|c|}
\hline \multirow{2}{*}{ Catalyst } & \multirow{2}{*}{ Clay } & \multirow{2}{*}{ Precursor } & \multirow{2}{*}{ Peg } & \multirow{2}{*}{ Water } & \multicolumn{2}{|c|}{ Mass losses } \\
\cline { 5 - 7 } & & & & & Drying & Calcination \\
\hline $\mathrm{AS}$ & 62 & 0 & 31 & 7 & 13 & 47 \\
\hline $\mathrm{AS} / \mathrm{Ca}$ & 21 & 52 & 11 & 16 & 16 & 46 \\
\hline $\mathrm{AS} / \mathrm{Mg}$ & 13 & 30 & 6 & 51 & 52 & 74 \\
\hline $\mathrm{AS} / \mathrm{Fe}$ & 22 & 44 & 12 & 22 & 19 & 32 \\
\hline
\end{tabular}

\section{Catalyst characteristics}

Elemental composition and basic properties of catalysts used in experiments are given in Table 3. Chemical composition of catalysts was determined by means of SEM-EDS (scanning electron microscope with X-ray microanalysis; Quanta 250). Total pore volume $\left(V_{T}\right)$ was determined by measurement of amount of nitrogen adsorbed at relative pressure of $\mathrm{PP}_{0}^{-1}=0.98$. Porous texture was calculated from nitrogen adsorption isotherms measured at $77 \mathrm{~K}$ with NOVA 2200 (Quantachrome). Specific surface area was determined with BET method. Supplementary porous texture tests were performed with PASCAL 440 porosimeter (CE Instruments) at pressure ranges from 0.003 to $400 \mathrm{MPa}$ and pore volumes in the range of radii from about $200 \mu \mathrm{m}$ to $1.8 \mathrm{~nm}$ were determined. The following parameters characterizing the porous texture of catalyst pellets were established: $A_{p}$ - total area of porosity (total surface calculated assuming cylindrical pores), $d_{V}$ - average pore diameter (calculated from volume of pores), $d_{A}$ - mean pore diameter (calculated from surface of pores). Micro-strength tests were performed in order to compare mechanical strength of pellets with different precursors. Tests were performed in rotating $30 \mathrm{~cm}$ long steel cylinder filled with steel balls. A weighed sample of the catalyst (about $1 \mathrm{~g}$ ) was rotated for 8 minutes at $25 \mathrm{rpm}$ then sieve analysis was performed for the determination of masses of grains with size $>1 \mathrm{~mm}, 0.5-1 \mathrm{~mm}, 0.2-0.5 \mathrm{~mm}$ and $<0.2 \mathrm{~mm}$. Finally, two parameters were calculated: micro-strength - R1 (the share of fraction above $0.5 \mathrm{~mm}$ ) and abrasion - R3 (the share of fraction less than $0.2 \mathrm{~mm}$ ).

Small $S_{B E T}$ area is characteristic of macroporous solids. These results are in correlation with porosimetric analysis, which also confirmed a dominant share of macropores. High proportion of mesopores is characteristic for this type of material. All catalysts are characterized by small total volume and small surface area. The density of catalysts increases from magnesium to iron type: $\mathrm{AS} / \mathrm{Mg}<\mathrm{AS} / \mathrm{Ca}<\mathrm{AS}<\mathrm{AS} / \mathrm{Fe}$, clearly depending on the precursor used for modification of the original clay. There is also a significant effect of the nature of precursor on both micro-strength and abrasion of the catalyst (see Table 3). The catalyst formed from the natural clay (AS) has good mechanical strength $(\mathrm{R} 1=90.6)$ whereas $\mathrm{AS} / \mathrm{Mg}$ and $\mathrm{AS} / \mathrm{Ca}$ exhibit a considerable decrease in mechanical strength and a strong increase of abrasion (R3 $>40 \%$ ) is observed. Addition of iron based precursor decreases the friability of pellets and increases the mechanical strength. 
Elemental composition and basic properties of clay-based catalysts

\begin{tabular}{|c|c|c|c|c|}
\hline & \multicolumn{4}{|c|}{ Catalyst } \\
\hline & $\mathbf{A S}$ & $\mathbf{A S} / \mathbf{C a}$ & AS/Mg & $\mathbf{A S} / \mathbf{F e}$ \\
\hline \multicolumn{5}{|c|}{ Content of selected elements [wt.\%] } \\
\hline $\mathrm{Mg}$ & 0.68 & 1.34 & 30.9 & 0.22 \\
\hline $\mathrm{Al}$ & 13.9 & 9.01 & 6.19 & 3.68 \\
\hline $\mathrm{Si}$ & 20.5 & 11.6 & 9.00 & 5.76 \\
\hline $\mathrm{K}$ & 1.36 & 0.33 & 0.46 & 0.44 \\
\hline $\mathrm{Ca}$ & 0.50 & 21.0 & 0.51 & 0.33 \\
\hline $\mathrm{Fe}$ & 6.64 & 2.18 & 2.71 & 50.5 \\
\hline $\mathrm{O}$ & 43.9 & 46.7 & 39.7 & 28.3 \\
\hline \multicolumn{5}{|c|}{ Porous texture parameters } \\
\hline$S_{B E T}\left[\mathrm{~m}^{2} / \mathrm{g}\right]$ & 12 & 16 & 34 & 7 \\
\hline$V_{\text {total }}\left[\mathrm{cm}^{3} / \mathrm{g}\right]$ & 0.024 & 0.027 & 0.095 & 0.012 \\
\hline$V_{\text {meso }} / V_{\text {total }}[\%]$ & 75 & 70 & 82 & 66 \\
\hline \multicolumn{5}{|c|}{ Porosimetric parameters } \\
\hline$A_{p}\left[\mathrm{~m}^{2} / \mathrm{g}\right]$ & 31 & 7 & 27 & 9 \\
\hline$d_{v}[\mu \mathrm{m}]$ & 0.111 & 0.322 & 0.178 & 0.138 \\
\hline$d_{A}[\mu \mathrm{m}]$ & 0.011 & 0.006 & 0.156 & 0.117 \\
\hline$d\left[\mathrm{~g} / \mathrm{cm}^{3}\right]$ & 2.12 & 2.01 & 1.62 & 3.35 \\
\hline \multicolumn{5}{|c|}{ Micro-strength parameters } \\
\hline $\mathrm{R} 1[\%]$ & 90.6 & 52.1 & 25.3 & 92.3 \\
\hline R3 [\%] & 7.5 & 43.1 & 42.8 & 5.6 \\
\hline
\end{tabular}

\section{Reactor and experimental procedure}

Experiments of gasification were performed in a simple quartz reactor, presented in Figure 2. Reactor was consisted of three tubes of diameters 22, 30 and $38 \mathrm{~mm}$ and length of 250, 550 and $750 \mathrm{~mm}$, respectively, arranged "one inside the other". Tops of the inner ones were covered with perforated steel separators, which were supports for the oat bed (lower plate, $15.0 \mathrm{~g}$ of oat) and catalytic layer (higher plate, catalytic layer usually of $10 \mathrm{~cm}$ height). The space above catalytic layer (end of the furnace and outside the furnace) was filled with expanded clay granules and the reactor was sealed at the top with temperature resistive siloxane layer put on a ceramic wool base. Bottom part of the reactor (all three quartz tubes) was immersed in a water seal, which was also a pressure buffer. There were two thermocouples of K-type placed in a thin quartz tube centrally in a reactor: in the gasified bed and in the catalytic layer. Temperatures measured by these thermocouples were recorded with APAR AR 206/8 digital controller/recorder. Reactor was heated by two tube furnaces which temperature profiles were programmed with Lumel RE15 and RE31 controllers supported by RP6 and RP7 1-phase power controllers. Water for steam generation $(0.60 \mathrm{~g} / \mathrm{min})$ was supplied by peristaltic pomp (Williamson Manufacturing Ltd 201.SMA.150.050) directly to the lower, inner tube and vaporized by the heat of the reactor.

Gases passing catalytic layer were removed from reactor by glass L-tube sealed in the siloxane layer and cooled down in a Liebig condenser. Aqueous condensates were collected in glass containers of 100 or $200 \mathrm{~cm}^{3}$ volume. Non-condensing gases passed through glass pressure buffer (of $1 \mathrm{dm}^{3}$ ) and water sealing were combusted in a small flare (if necessary). Any experiment began with one hour flushing of the reactor and gas line with argon and preliminary overnight heating the oat bed to $110^{\circ} \mathrm{C}$ and catalytic bed to $250^{\circ} \mathrm{C}$ (in order to remove free moisture). After that, temperature of the catalyst bed was increased with the 
rate of $15^{\circ} \mathrm{C} / \mathrm{min}$ up to $900^{\circ} \mathrm{C}$ then the oat bed was heated with the rate of $4^{\circ} \mathrm{C} / \mathrm{min}$ up to $800^{\circ} \mathrm{C}$. Feeding of the reactor with steam was started when the oat bed temperature was higher than $140^{\circ} \mathrm{C}$ and proceeded up to the end of experiment and cooling down reactor below $500^{\circ} \mathrm{C}$. Steam flow of approximately $0.60 \mathrm{~g} / \mathrm{min}$ was higher than stoichiometric needs of gasification process, as it was discussed later (continuous condensation of steam was observed in all experiments immediately after steam feeding was started).
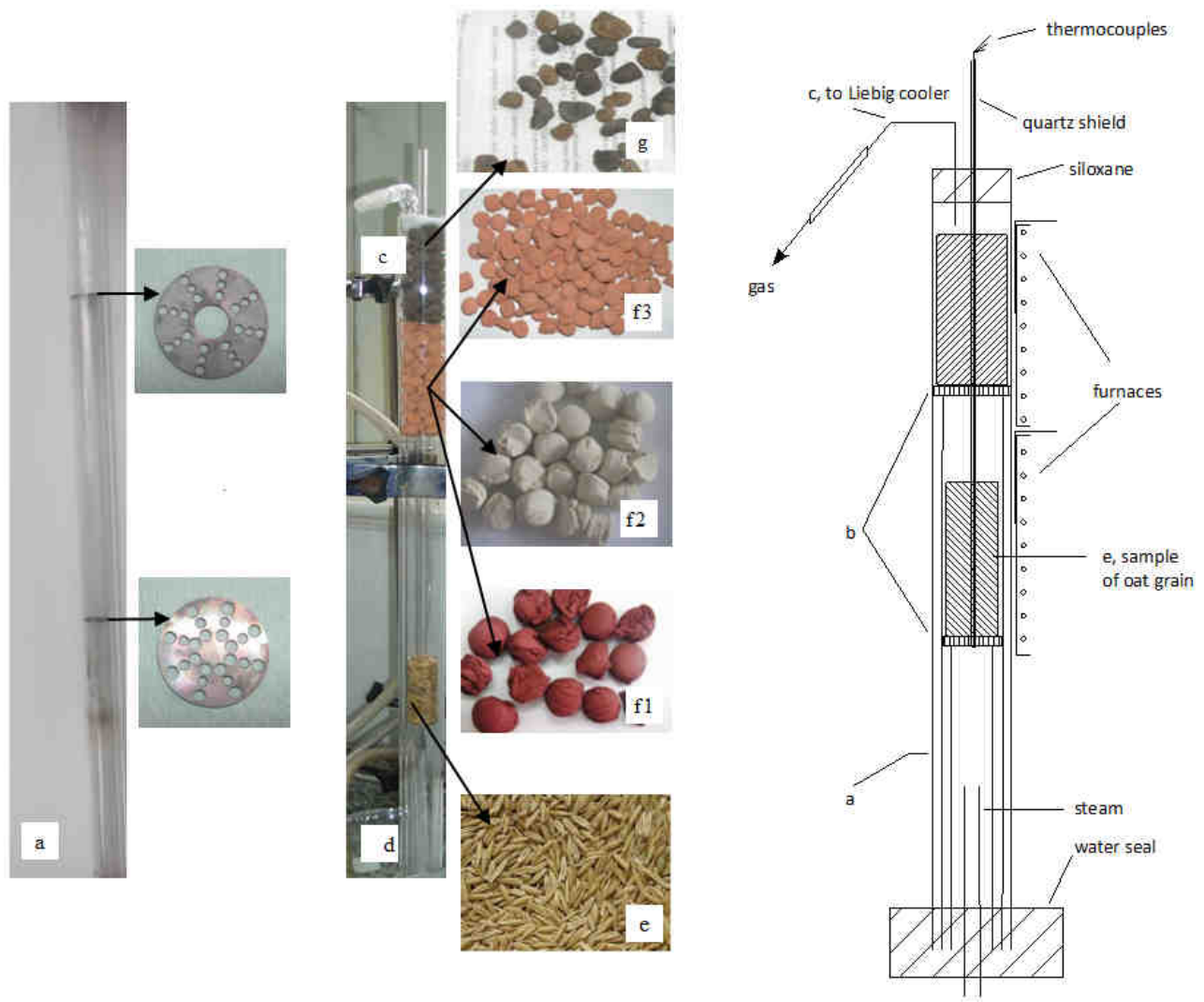

Fig. 2. Quartz reactor used in gasification experiments: a) quartz tubes, b) steel separators, c) glass L-tube, d) completed reactor with oat, e), f) catalytic elements with oxides of iron (f1), magnesium (f2) and calcium (f3), g) expanded clay (above catalytic elements)

\section{GC-MS analysis}

Condensing phases were generally observed in a glass tube (exit of gases from reactor) and Liebig condenser. Non-aqueous phases from Liebig condenser were almost completely flushed by condensing steam to the container. These deposits were carefully removed after each experiment with acetone wetted pieces of cotton wool then extracted with diethyl ether (p.a. grade, POCh S.A.) together with aqueous condensate. As a result, $40 \mathrm{~cm}^{3}$ of the extract was prepared in each experiment. This extract $\left(1 \mathrm{~mm}^{3}\right.$ of the solution) was analyzed with HP6890 gas chromatograph equipped with HP5973 mass selective detector and HP-1701 capillary column $(30 \mathrm{~m} \times 0.25 \mathrm{~mm}$ i.d., $0.25 \mu \mathrm{m}$ film thickness, 
14\%-cyanopropylphenyl-86\%-dimethyl-siloxane polymer). As a carrier helium gas (purity $99.999 \%$ ) was used. The column temperature was steadily increased from 40 to $250^{\circ} \mathrm{C}$ at $10^{\circ} \mathrm{C} / \mathrm{min}$ after an initial 3 minutes of isothermal period then kept at the final temperature for 10 minutes. The inlet was set at $250^{\circ} \mathrm{C}$. Sample injection was made in the split mode (1:10). Mass spectrometer was set at an ionizing voltage of $70 \mathrm{eV}$ with mass range $\mathrm{m} / \mathrm{z}$ 15-400. Identification of organic compounds was accomplished by comparing mass spectra of the resolved components using NIST electronic library search routines.

\section{Results and discussion}

\section{Summary of parameters of experiments}

There were five experiments performed in this investigation - four with catalyst pellets (AS, AS/Ca, AS/Fe, AS/Mg) and one with quartz pieces (tubes) of $2 \mathrm{~cm}$ length and diameter of $4 \mathrm{~mm}$ as a reference (Q). Details of experiments have been collected in the Table 4. The same amount of oat grains was used in all experiments $(15 \mathrm{~g})$. Gasification run usually took 5-6 hours, with exception of experiment with AS/Fe catalyst which was continued for more than 7 hours (measured as the time of steam supply). Masses of catalytic bed varied from 20 to $70 \mathrm{~g}$ depending on catalytic precursor (AS, AS/Ca, AS/Fe, $\mathrm{AS} / \mathrm{Mg}$ ). Total volume of steam supplied depended on time of the experiment (and is also given in the Table 4). It should be noticed that masses of catalytic beds after experiments were generally close to initial ones and their small decrease should be related only with mechanical loses.

Table 4

Parameters of gasification experiments. Notation of catalysts: Q - quartz (reference), AS - clay without additives, $\mathrm{AS} / \mathrm{Ca}$ - clay with $\mathrm{CaCO}_{3}$ (precursor), $\mathrm{AS} / \mathrm{Mg}$ - clay with $4 \mathrm{MgCO}_{3} \cdot \mathrm{Mg}(\mathrm{OH})_{2} \cdot 5 \mathrm{H}_{2} \mathrm{O}$ (precursor), AS/Fe - clay with $\mathrm{Fe}_{2} \mathrm{O}_{3}$ (precursor)

\begin{tabular}{|c|c|c|c|c|}
\hline \multicolumn{5}{|c|}{ Catalyst } \\
\hline Q & AS & $\mathrm{AS} / \mathrm{Ca}$ & $\mathrm{AS} / \mathrm{Mg}$ & $\mathrm{AS} / \mathrm{Fe}$ \\
\hline \multicolumn{5}{|c|}{ temperature of oat bed / temperature of catalyst bed } \\
\hline \multicolumn{5}{|c|}{$800^{\circ} \mathrm{C} / 900^{\circ} \mathrm{C}$} \\
\hline \multicolumn{5}{|c|}{ mass of oat grains $[\mathrm{g}]$} \\
\hline 14.99 & 14.93 & 15.01 & 15.16 & 15.36 \\
\hline \multicolumn{5}{|c|}{ mass of catalyst before (after) gasification $[\mathrm{g}]$} \\
\hline- & $55.44(55.03)$ & $42.39(40.11)$ & $21.60(21.45)$ & $76.90(73.75)$ \\
\hline \multicolumn{5}{|c|}{$\begin{array}{c}\text { flow of steam }[\mathrm{g} / \mathrm{min}] \\
0.603\end{array}$} \\
\hline \multicolumn{5}{|c|}{ total mass of supplied steam [g] } \\
\hline 202 & 181 & 192 & 200 & 278 \\
\hline \multicolumn{5}{|c|}{ solid residue after gasification (ash) [g] (wt.\% of initial oat grains) } \\
\hline $0.57(3.80 \%)$ & $0.90(6.30 \%)$ & $1.15(7.66 \%)$ & $0.61(4.03 \%)$ & $0.75(4.90 \%)$ \\
\hline
\end{tabular}

\section{Completeness of gasification}

Final solid residue of gasification process was grey or dark grey and its mass varied from 3.8 to 7.7 wt.\% of original mass of the sample (Table 4). Although completeness of the process was not the aim of experiments, it should be noticed that gasification rate of carbonaceous residue was slow even for pieces with diameter of typical grain and considerably increased with increase of temperature. 


\section{Effect of catalyst on tar reforming}

There were three parts of the reactor and condensation line, where nonvolatile products could be separated from gaseous phase: short glass L-tube sealed in siloxane layer (Fig. 2c), Liebig condenser and glass container for aqueous condensate, all connected by ground glass joints greased with high temperature silicone grease. Soot and high temperature condensing tar could be deposited directly in the L-tube.

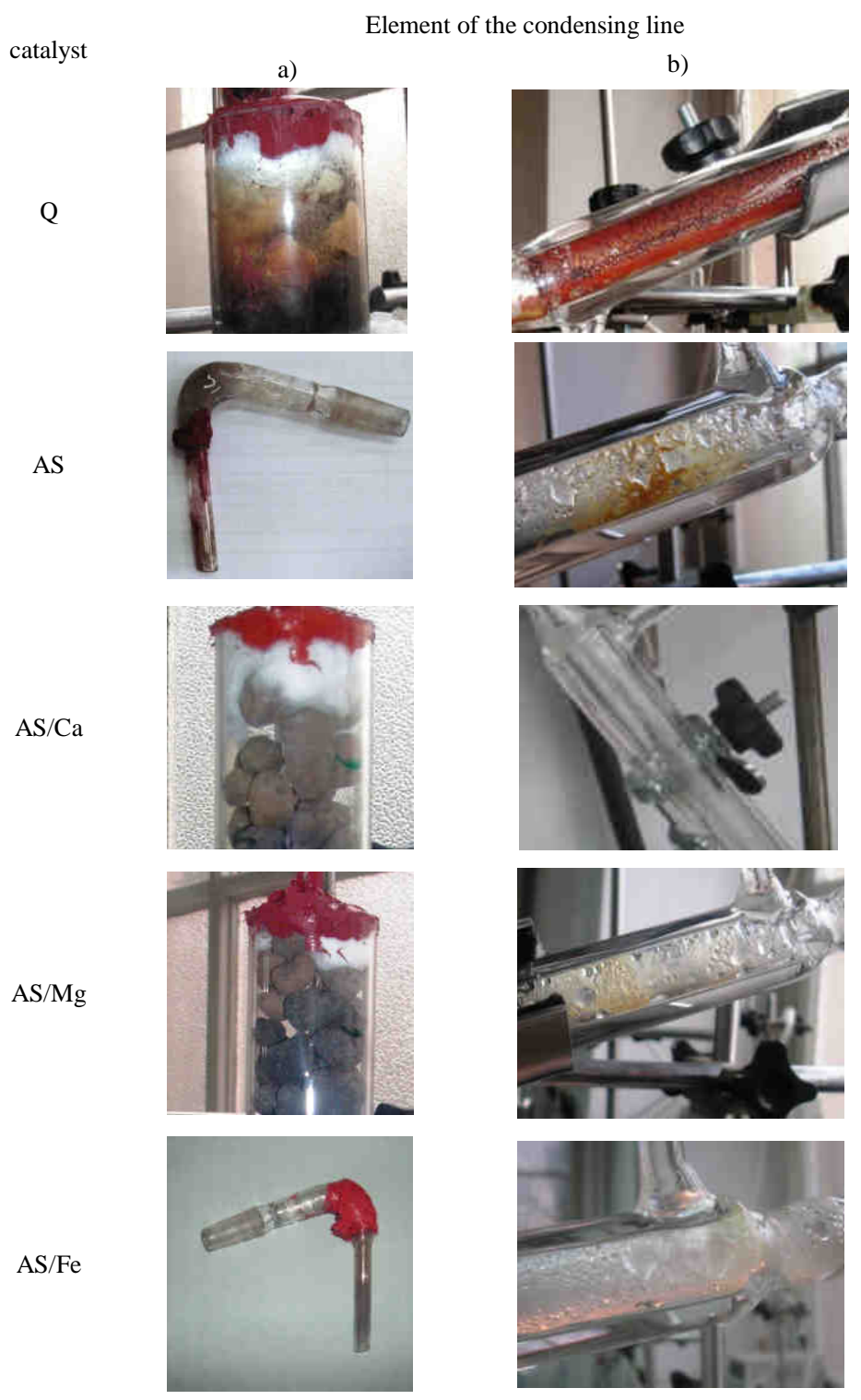

Fig. 3. Appearance of outlet of the reactor (a) and Liebig condenser (b) immediately after experiments 
Condensing in lower temperatures, greasy tar should condense in a Liebig condenser. Some condensates could be washed out by condensing steam from the condenser to the glass container. Gases from condensation line were removed by transparent polyethylene tube to glass buffer, so any further condensates (not removed in the condensation part) could be observed here. Because such deposits were not observed, it was assumed that dominant part of nonvolatile substances was removed in the condensation line. A visual comparison of (1) and (2) parts of condensation line after experiments, as it was presented in the Figure 3, was a tentative way of evaluation of catalyst efficiency in elimination of condensable substances from gaseous phase. It is easy to notice that even such qualitative evaluation clearly indicates that $\mathrm{Ca}, \mathrm{Mg}$ and $\mathrm{Fe}$ catalysts seems to be quite efficient. But it should be also noted that original, not modified clay without additives supported tar reforming (see Table 5).

Table 5

List of compounds identified in tars from non-catalytic and catalytic gasification of oat grains

\begin{tabular}{|c|c|c|c|c|c|c|c|}
\hline \multirow[b]{2}{*}{ No } & \multirow[b]{2}{*}{ Compound } & \multirow{2}{*}{$\begin{array}{c}\text { Molar } \\
\text { mass } \\
{[\mathrm{g} / \mathrm{mol}]} \\
\end{array}$} & $\mathbf{Q}$ & $\mathbf{A S}$ & AS/Ca & $\mathbf{A S} / \mathbf{M g}$ & $\mathbf{A S} / \mathbf{F e}$ \\
\hline & & & \multicolumn{5}{|c|}{ Mass of the compound [mg] } \\
\hline 1 & Benzonitrile & 103 & 1.71 & 0.83 & & 0.05 & 0.07 \\
\hline 2 & Naphthalene & 128 & 24.45 & 3.71 & 0.11 & 2.38 & 0.9 \\
\hline 3 & Benzo[b]thiophene & 134 & 0.35 & & & & \\
\hline 4 & Quinoline & 129 & 0.92 & & & & \\
\hline 5 & 1-Methylnaphthalene & 142 & 0.56 & & & 0.03 & \\
\hline 6 & Isoquinoline & 129 & 0.18 & & & & \\
\hline 7 & 2-Methylnaphthalene & 142 & 0.41 & & & 0.02 & \\
\hline 8 & Indole & 117 & 0.73 & & & & \\
\hline 9 & 2-Ethenylnaphthalene & 154 & 0.78 & & & & \\
\hline 10 & Acenaphthylene & 152 & 7.67 & 0.23 & & 0.04 & \\
\hline 11 & Acenaphthene & 154 & 0.16 & 0.3 & & 0.21 & 0.02 \\
\hline 12 & Dibenzofuran & 168 & 0.31 & 0.07 & & 0.02 & 0.08 \\
\hline 13 & Fluorene & 166 & 2.73 & & & & \\
\hline 14 & Phenanthrene & 178 & 13.46 & 2.82 & 0.14 & 1.21 & 0.24 \\
\hline 15 & Anthracene & 178 & 4.19 & 0.37 & & 0.16 & \\
\hline 16 & Acridine & 179 & 0.52 & & & & \\
\hline 17 & Benzo[f]quinoline & 179 & 0.6 & & & 0.08 & \\
\hline 18 & 2-Phenylnaphthalene & 204 & 2.02 & 0.28 & & 0.11 & \\
\hline 19 & Fluoranthene & 202 & 9.27 & 2.85 & 0.54 & 1.04 & 0.97 \\
\hline 20 & Pyrene & 202 & 11.3 & 1.08 & 0.06 & 0.32 & 0.11 \\
\hline 21 & 2-Methylpyrene & 216 & 0.81 & & & & \\
\hline 22 & Benz[a]anthracene & 228 & 1.28 & & & & \\
\hline 23 & Benzo[ghi]fluoranthene & 252 & 1.6 & & & & \\
\hline 24 & Triphenylene & 228 & 1.74 & & & & \\
\hline 25 & Benzo[a]pyrene & 252 & 0.75 & & & & \\
\hline 26 & Benzo[k]fluoranthene & 252 & 1.22 & & & & \\
\hline \multirow[t]{2}{*}{27} & Perylene & 252 & 0.79 & & & & \\
\hline & \multicolumn{2}{|c|}{ Sum of masses [mg]: } & 90.51 & 12.54 & 0.85 & 5.67 & 2.39 \\
\hline
\end{tabular}




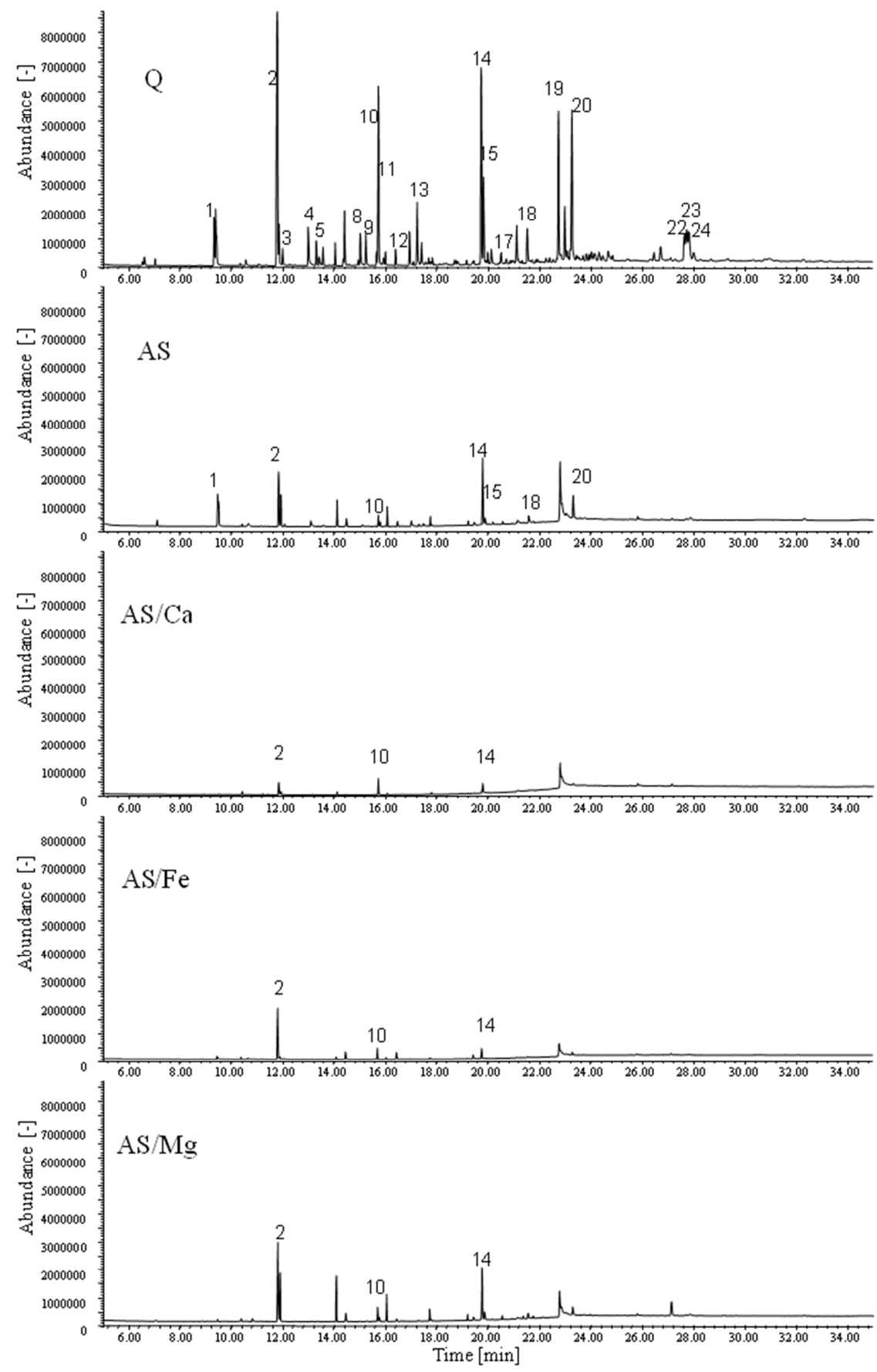

Fig. 4. Chromatograms of GC-MS analysis - the effect of clay catalyst specimen on the composition of tar formed during steam gasification of oat grains. Peak numbers correspond to compounds listed in Table 5 
Detailed examination of condensates has been performed with gas chromatography/mass spectrometry. Results of analysis are presented in Table 5 and Figure 4. Generally, variety of organics with high concentration was found only in non-catalyzed experiment with reactor filled with pieces of quartz. Total mass of compounds identified in this experiment (Q) was equal to $90.5 \mathrm{mg}$ (for $15 \mathrm{~g}$ of the oat grains sample). The use of clay catalyst without additives (AS) decreased emissions of organic species to $12.5 \mathrm{mg}$ (ie by $86 \%$ ). In experiments with modified catalysts $\mathrm{AS} / \mathrm{Ca}$ (clay $+\mathrm{CaCO}_{3}$ ) and $\mathrm{AS} / \mathrm{Fe}$ (clay $+\mathrm{Fe}_{2} \mathrm{O}_{3}$ ) tar was not observed as a separate phase in any part of a gas line (particularly in a Liebig condenser and container for condensate). Any additive to original clay efficiently decreased emission of condensing phases: magnesium $(\mathrm{Mg})$ to $5.7 \mathrm{mg}$ (by $94 \%$ in comparison with the quartz reference), iron (Fe) to $2.4 \mathrm{mg}$ (by $97 \%$ ) and calcium (Ca) to $0.85 \mathrm{mg}$ (by more than $99 \%$ ). Nevertheless, some individuals were found in all condensate samples: naphthalene, phenanthrene, pyrene and fluoranthene (Table 5). Some others were detected only in selected samples ( $\mathrm{g}$ benzonitrile and acenaphthene were present in all samples with exception of AS/Ca condensate).

It can therefore be assumed, in accordance with above observations, that gaseous species from pyrolytic degradation of oat biomass were efficiently converted even with original natural aluminosilicate and almost completely with this modified substrate. Catalytic activity of catalyst pellets used for tar reforming is related with presence of acidic sites. Experiments demonstrated that effectiveness of AS catalyst may be improved by simple mixing with calcium or magnesium carbonates and iron oxides, which are well known as catalysts for tar elimination [16]. It should be emphasized that the excess of steam supports not only gasification of carbonaceous residue but also enhances elimination of nonvolatile contaminants from gaseous phase during steam condensation. Condensate, aqueous and non-aqueous phases (if there will be any), could be recycled to the reactor, so the solid mineral residue from gasification and gas, rich in hydrogen, would be the only products from this process.

\section{HSC software calculations and discussion}

Composition of the gas in thermodynamic equilibrium (supported by catalyst) depends on characteristics of gases evolved from oat grains in the process and their proportion to the steam. While the amount of steam introduced into the process was kept constant at the $0.60 \mathrm{~g} / \mathrm{min}$ level, pyrolysis of oat generated, depending on temperature, variable amounts of gaseous individuals. Assuming that gaseous phase should be in chemical equilibrium (or close to the equilibrium in the catalytic part of the reactor; this was the idea of experiment), composition of gas in the pyrolytic stage of the process was calculated with Outokumpu HSC Chemistry ${ }^{\circledR}$ for Windows software [20] for two cases: (1) steady gas evolution or (2) maximum of gas evolution. The rate of oat grains decomposition was calculated on the basis of thermogravimetric investigations described in the paper of Poskropko and Krol [21], taking into account TG and DTG curves for oat grains sample heating under argon. DTG peak of oat decomposition starts at $230^{\circ} \mathrm{C}$ and ends at $520^{\circ} \mathrm{C}$, if deviation of the curve from base line is considered. But the last part of the peak is clearly diffused due to overlapping of two effects; the first corresponds to dominating endothermic peak with maximum at $299^{\circ} \mathrm{C}$ and the second (at temperature near $400^{\circ} \mathrm{C}$ ), small and 'shapeless', seems to be responsible for this diffusion. In order to determine temperature range of intensive gas evolution from the oat grains sample, temperatures of intersections of peak tangents with basic line were found: $250^{\circ} \mathrm{C}$ (increasing) and $330^{\circ} \mathrm{C}$ (decreasing). 
Therefore, for the variant of steady gas evolution the temperature range of $80^{\circ} \mathrm{C}$ was assumed and, for heating rate of $4^{\circ} \mathrm{C} / \mathrm{min}$, intensive gas evolution lasted 20 minutes. Assuming that through this period volatile carbon as well as hydrogen, oxygen, nitrogen and sulfur were transferred to the gas phase as volatile matter (Table 1), approximately $0.56 \mathrm{~g} / \mathrm{min}$ of volatile matter was released. Considering the variant of maximum gas evolution it should be noticed that authors of the paper [21] found that maximum of the sample mass decrease (at $299^{\circ} \mathrm{C}$ ) was equal to $12.98 \% / \mathrm{min}$. Taking into account that the mass of $15.0 \mathrm{~g}$ of oat grains was used in each experiment, it corresponds up to $1.95 \mathrm{~g} / \mathrm{min}$ of the gas emission. Results of calculations are presented in Table 6. They show that amount of steam supplied to the reactor was satisfactory even for maximum gas evolution alternative although the calculated steam concentration was less at equilibrium than 5 vol.\%. For more realistic variant, steady gas evolution, calculated equilibrium concentration of steam was equal to 26.2 vol.\%. Concentrations of other gases are respectively correlated - with higher values of $\mathrm{H}_{2}, \mathrm{CO}$ and lower value of $\mathrm{CO}_{2}$ for the case of maximum gas evolution.

Table 6

Gas phase composition for steady and maximum gas evolution variants (details in the text) of oat grains pyrolysis initial data and results of calculations with HSC [20] software

\begin{tabular}{|c|c|c|c|c|}
\hline & \multicolumn{2}{|c|}{ Variant of steady gas evolution } & \multicolumn{2}{c|}{ Variant of maximum gas evolution } \\
\hline Component & $\begin{array}{c}\text { Initial data } \\
\text { [mol/min] }\end{array}$ & $\begin{array}{c}\text { Calculated gas composition } \\
\text { [mol \%] }\end{array}$ & $\begin{array}{c}\text { Initial data } \\
\text { [mol/min] }\end{array}$ & $\begin{array}{c}\text { Calculated gas composition } \\
\text { [mol \%] }\end{array}$ \\
\hline $\mathrm{H}_{2}$ & $2.35 \cdot 10^{-2}$ & 45.9 & $8.21 \cdot 10^{-2}$ & 55.6 \\
\hline $\mathrm{O}_{2}$ & $7.76 \cdot 10^{-3}$ & & $2.71 \cdot 10^{-2}$ & \\
\hline $\mathrm{N}_{2}$ & $4.93 \cdot 10^{-4}$ & 0.65 & $1.72 \cdot 10^{-3}$ & 0.92 \\
\hline $\mathrm{S}_{2}$ & $1.99 \cdot 10^{-5}$ & & $6.95 \cdot 10^{-5}$ & \\
\hline $\mathrm{H}_{2} \mathrm{~S}$ & & 0.053 & & 0.075 \\
\hline $\mathrm{C}$ & $2.06 \cdot 10^{-2}$ & & $7.19 \cdot 10^{-2}$ & \\
\hline $\mathrm{CO}$ & & 18.9 & & 36.0 \\
\hline $\mathrm{CO}$ & & 8.28 & & 2.43 \\
\hline $\mathrm{H}_{2} \mathrm{O}($ steam) & $3.11 \cdot 10^{-2}$ & 26.2 & $3.11 \cdot 10^{-2}$ & 4.89 \\
\hline $\mathrm{CH}_{4}, \mathrm{NH}_{3}$ & & $<0.01$ & & $<0.1$ \\
\hline
\end{tabular}

Described here experiments lasted more than four hours each. Major gas emission (in the pyrolytic phase) proceeded up to less than $500^{\circ} \mathrm{C}$, ie during first 160 minutes, practically in the final 30 minutes of this period. Then gas evolution considerably decreased and steam gasification of $2.25 \mathrm{~g}$ of $\mathrm{C}_{\text {nonvolatile }}$ (fixed carbon - Table 1) proceeded up to the end of experiment. At this stage of experiment emission of gas increased due to increase of temperature but decreased due to vanishing of the char (to practically zero emission at the end of experiment). Because this phase of gasification is less important for the global gas composition, it was assumed that emission was stable during this stage. With this assumption calculated gas composition was dominated by steam (92.2 vol.\%) with 5.2 vol. \% of $\mathrm{H}_{2}, 2.5$ vol.\% of $\mathrm{CO}_{2}$ and only 0.18 vol.\% of $\mathrm{CO}$.

It is easy to notice from Table 6 that there is significant difference between equilibrium concentrations of $\mathrm{CO}_{2}$ and $\mathrm{CO}$ for steady state and maximum of gas evolution variants (period of pyrolysis). The same concerns the stage of the residual char gasification (above). Consequently, speciation of active catalytic elements ( $\mathrm{Ca}, \mathrm{Mg}$ and $\mathrm{Fe}$ ) should be depended on the partial pressure of $\mathrm{CO}_{2}$ and proportion of $\mathrm{p}_{\mathrm{CO}_{2}}$ to $\mathrm{p}_{\mathrm{CO}}$. In the case of iron oxide, reaction $\mathrm{FeO}+\mathrm{CO}=\mathrm{Fe}+\mathrm{CO}_{2}$ should be taken into account. Its equilibrium constant, 
$\mathrm{K}=\mathrm{p}_{\mathrm{CO}_{2}} / \mathrm{p}_{\mathrm{CO}}$, varies from 0.91 at $600^{\circ} \mathrm{C}$ to $0.48_{5}$ at $900^{\circ} \mathrm{C}$ [20]. The later value may be compared with data in Table 6. In more general view, temperature dependence of this relation may be considered and it was presented in Figure 5a. The line denoted by $\mathrm{Fe}$ represents equilibrium constant of reduction reaction of $\mathrm{FeO}$ to metallic $\mathrm{Fe}$, whereas lines 2 and 3 proportions of $\mathrm{CO}_{2}$ to $\mathrm{CO}$ for steady state and maximum of gas evolution variants. Line 1 is the ratio of $\mathrm{CO}_{2}$ to $\mathrm{CO}$ for the stage of char gasification (all calculations were performed with HSC Chemistry® for Windows software [20]). Intersections of lines indicate temperatures of $\mathrm{FeO}$ reduction to $\mathrm{Fe}: 628^{\circ} \mathrm{C}$ for variant of maximum gas evolution and $783^{\circ} \mathrm{C}$ for the steady state one. However, in the final stage of the process, ie char gasification, metallic Fe is oxidized back to $\mathrm{FeO}$ (line 1 in Fig. 5a).
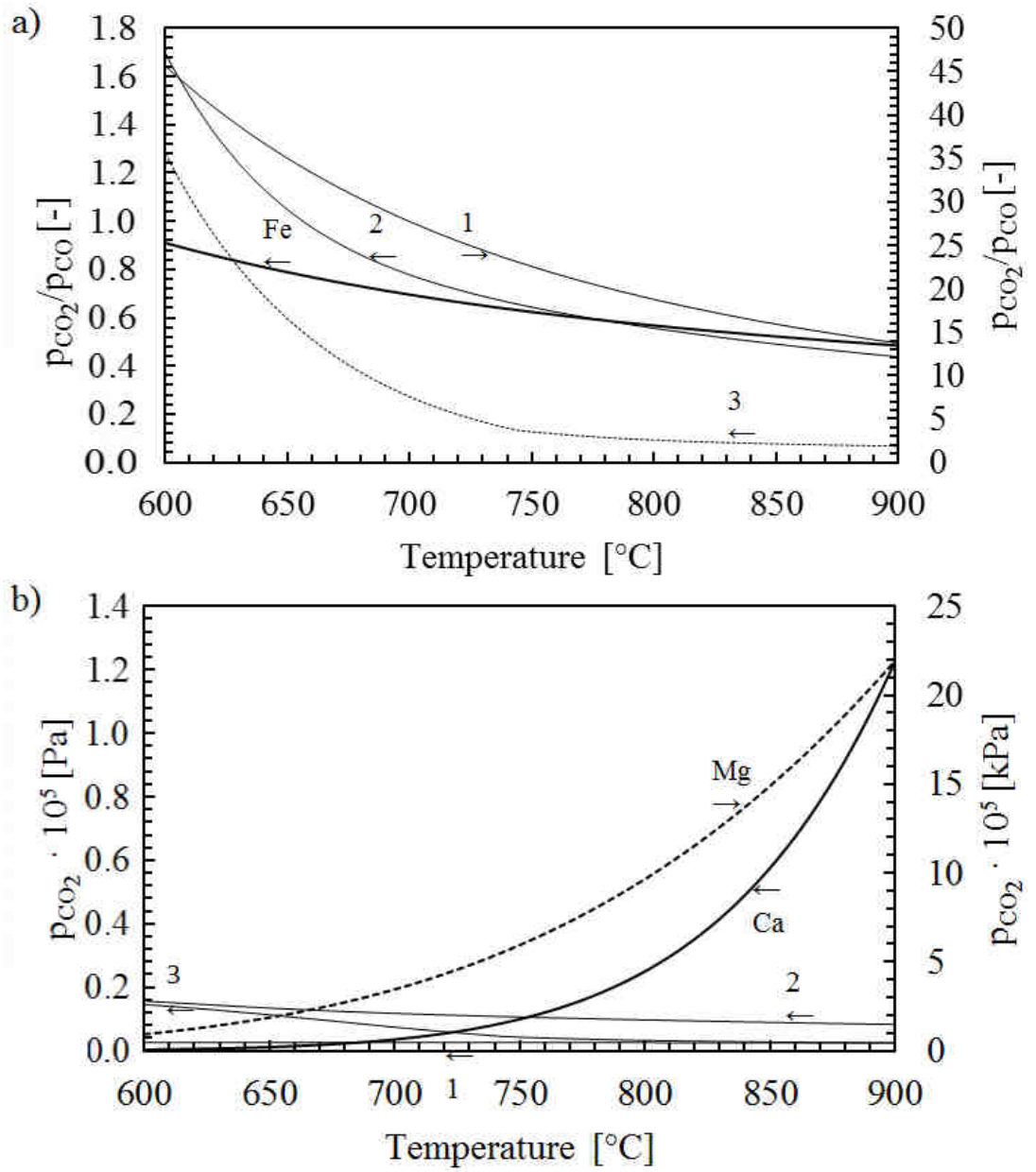

Fig. 5. a) Equilibrium $\mathrm{p}_{\mathrm{CO}_{2}} / \mathrm{p}_{\mathrm{CO}}$ for $\mathrm{FeO}+\mathrm{CO}=\mathrm{Fe}+\mathrm{CO}_{2}$ reaction compared with respective $\mathrm{p}_{\mathrm{CO}} / \mathrm{p}_{\mathrm{CO}}$ ratios for the steady state (2) and maximum (3) of gas evolution variants and for the period of residual char gasification (1, right axis). b) Equilibrium pressures of $\mathrm{CO}_{2}$ for $\mathrm{MgCO}_{3}(\mathrm{Mg}$, right axis) and $\mathrm{CaCO}_{3}\left(\mathrm{Ca}\right.$, left axis) compared with partial pressures of $\mathrm{CO}_{2}$ for the steady state (2) and maximum (3) of gas evolution variants and for the period of residual char gasification (1) 
In the next Figure 5b, the equilibria between carbonates and oxides of calcium and magnesium are compared with partial pressures of $\mathrm{CO}_{2}$ characteristic for discussed variants of experimental situation. It should be emphasized that equilibrium pressures over magnesium and calcium carbonates are very different - equilibrium constant of the reaction $\mathrm{MgCO}_{3}=\mathrm{MgO}+\mathrm{CO}_{2}$ increases from 934 at $600^{\circ} \mathrm{C}$ to $2.19 \cdot 10^{4}$ at $900^{\circ} \mathrm{C}$ (right axis in Fig. 5b) whereas the constant of reaction $\mathrm{CaCO}_{3}=\mathrm{CaO}+\mathrm{CO}_{2}$ changes from only $3.20 \cdot 10^{-3}$ at $600^{\circ} \mathrm{C}$ to 1.23 at $900^{\circ} \mathrm{C}$ (left axis in Fig. 5b). Of course, it is clear that at high temperatures (near $900^{\circ} \mathrm{C}$ ) only magnesium and calcium oxides are phases which may be taken into account in gasification process. However, in the case of calcium it should be noted that the $\mathrm{CaCO}_{3}$ phase should be stable below $753^{\circ} \mathrm{C}$ in the variant of steady state gas evolution. It may be therefore concluded that, for the experiment with AS/Fe catalyst, iron was in the metallic form only for intensive gas evolution during pyrolytic phase of the gasification process. At lower gas emissions iron should be oxidized to FeO. On the other hand, calcium and magnesium should stay in the oxide form.

Cooling gas in Liebig condenser caused condensation of steam. Taking into account number of moles of the gas constituents (from HSC calculations) and assuming that equilibrium gas composition was preserved during cooling, it was possible to calculate total volume of the gas (both from pyrolysis stage and char gasification phase). It was, on the dry basis, $41.2 \mathrm{dm}^{3}$ (at $25^{\circ} \mathrm{C}$ and $10^{5} \mathrm{~Pa}$ the water vapor constitutes $3.17 \%$ of the gas volume). Therefore, overall composition of the gas (on the dry basis) was: $63.5 \%$ vol. $\mathrm{H}_{2}, 18.0 \%$ vol. $\mathrm{CO}_{2}, 17.9$ vol.\% $\mathrm{CO}, 0.59$ vol. $\% \mathrm{~N}_{2}$ and traces of methane (<0.1 vol.\%). Calculated GCV (gross calorific value) of the gas was $8.3 \mathrm{MJ} / \mathrm{m}^{3}$ (at $25^{\circ} \mathrm{C}$ and $10^{5} \mathrm{~Pa}$ ). Taking into account gas volume and its calorific value, there is $31 \%$ more energy in the product gas than in the original oat grains sample. This 'excess' energy represents 'chemical' energy of the steam consumed in the process.

\section{Conclusions}

Laboratory experiments of the oat grains gasification under steam at normal (atmospheric) pressure have been performed. Experiments were carried out in a vertical quartz reactor, with a steady flow of steam and instantaneous (without cooling) converting of gaseous species from pyrolysis of biomass on the catalytic bed prepared from local clay (aluminosilicate) with inexpensive additives. There were four catalysts employed: clay pellets alone and clay modified with calcium carbonate, magnesium carbonate or iron oxide. Quartz pellets were used as a nonreactive reference bed. Condensation of the excess of steam efficiently supported elimination of non-volatile components (tar, oil) from gaseous phase. Condensates were analyzed with GC-MS for origins and quantity of organic species. Only four species were found in all examined samples, namely: naphthalene, phenanthrene, pyrene and fluoranthene. Benzonitrile and acenaphthene were not detected in samples from experiment with calcium catalyst. As it was expected, the highest level of organic components was found in the condensate from experiment with non-catalytic bed of quartz elements. There was characteristic decrease of the concentration of organic species in condensate in comparison with non-catalytic (quartz) bed to $14 \%$ for original clay without additives (precursors), $6 \%$ for clay with magnesium $(\mathrm{Mg}), 3 \%$ with iron $(\mathrm{Fe})$ and less than $1 \%$ with calcium $(\mathrm{Ca})$. These condensates may be recycled to the gasifying reactor. The process is allothermal, but the energy is transferred to generated gas. 


\section{Acknowledgements}

The work was co-financed by a Grant No. 14.0016.10 of The National Centre for Research and Development (agency of the Minister of Science and Higher Education, Republic of Poland) and statutory activity subsidies from the Polish Ministry of Science and Higher Education for the Faculty of Chemistry of Wroclaw University of Technology. The authors would like to thank J. Liberkowska for her technical support during catalysts preparation.

\section{References}

[1] Van de Velden M, Baeyens J, Brems A, Janssens B, Dewil R. Fundamentals, kinetics and endothermicity of the biomass pyrolysis reaction. Renew Energy. 2010;35:232-242. DOI: 10.1016/j.renene.2009.04.019.

[2] Baruah D, Baruah DC. Modeling of biomass gasification: A review. Renew Sust Energy Rev. 2014;39:806-815. DOI: 10.1016/j.rser.2014.07.129.

[3] Sharma A, Pareek V, Zhang D. Biomass pyrolysis - A review of modelling, process parameters and catalytic studies. Renew Sust Energy Rev. 2015;50:1081-1109. DOI: 10.1016/j.rser.2015.04.193.

[4] Heidenreich S. Foscolo PU. New concepts in biomass gasification. Prog Energy Combust Sci. 2015;46:72-95. DOI: 10.1016/j.pecs.2014.06.002.

[5] Ruiz JA, Juárez MC, Morales MP, Muñoz P, Mendívil MA. Biomass gasification for electricity generation: Review of current technology barriers. Renew Sust Energy Rev. 2013;18:174-183. DOI: 10.1016/j.rser.2012.10.021.

[6] Abdoulmoumine N, Adhikari S, Kulkarni A, Chattanathan S. A review on biomass gasification syngas cleanup. Appl Energy. 215;155:294-307. DOI: 10.1016/j.apenergy.2015.05.095.

[7] Shen Y, Yoshikawa K. Recent progresses in catalytic tar elimination during biomass gasification or pyrolysis - A review. Renew Sust Energy Rev. 2013;21:371-392. DOI: 10.1016/j.rser.2012.12.062.

[8] Chan FL, Tanksale A. Review of recent developments in Ni-based catalysts for biomass gasification. Renew Sust Energy Rev. 2014;38:428-438. DOI: 10.1016/j.rser.2014.06.011.

[9] Xu X, Jiang E, Wang M, Xu Y. Dry and steam reforming of biomass pyrolysis gas for rich hydrogen gas. Biomass Bioenerg. 2015;78:6-16. DOI: 10.1016/j.biombioe.2015.03.015.

[10] Lan W, Chen G, Zhu X, Wang X, Xu B. Progress in techniques of biomass conversion into syngas. J Energy Inst. 2015;88:151-156. DOI: 10.1016/j.joei.2014.05.003.

[11] Meng X, de Jong W, Verkooijen AHM. Biomass gasification in a $100 \mathrm{kWth}$ steam-oxygen blown circulating fluidized bed gasifier: Effects of operational conditions on product gas distribution and tar formation. Biomass Bioenerg. 2011;35:2910-2924. DOI: 10.1016/j.biombioe.2011.03.028.

[12] Wilk V, Hofbauer H. Conversion of mixed plastic wastes in a dual fluidized bed steam gasifier. Fuel. 2013;107:787-799. DOI: 10.1016/j.fuel.2013.01.068.

[13] Gallmetzer G, Ackermann P, Schweiger A, Kienberger T, Gröbl T, Walter H, et al. The agnion Heatpipe-Reformer - operating experiences and evaluation of fuel conversion and syngas composition. Biomass Conv Bioref. 2012;2:207-215. DOI: 10.1007/s13399-012-0046-2.

[14] Panopoulos KD, Fryda LE, Karl J, Poulou S, Kakaras E. High temperature solid oxide fuel cell integrated with novel allothermal biomass gasification Part I: Modelling and feasibility study. J Power Sources. 2006;159:570-585. DOI: 10.1016/j.jpowsour.2005.12.024

[15] Xu C (Charles), Donald J, Byambajav E, Ohtsuka Y. Recent advances in catalysts for hot-gas removal of tar and $\mathrm{NH}_{3}$ from biomass gasification. Fuel. 2010;89:1784-1795. DOI: 10.1016/j.fuel.2010.02.014.

[16] Nordgreen T, Nemanova V, Engvall K, Sjöström K. Iron-based materials as tar depletion catalysts in biomass gasification: Dependency on oxygen potential. Fuel. 2012;95:71-78. DOI: 10.1016/j.fuel.2011.06.002.

[17] Nzihou A, Stanmore B, Sharrock P. A review of catalysts for the gasification of biomass char, with some reference to coal. Energy. 2013;58:305-317. DOI: 10.1016/j.energy.2013.05.057.

[18] de Lasa H, Salaices E, Mazumder J, Lucky R. Catalytic steam gasification of biomass: catalysts, thermodynamics and kinetics. Chem Rev. 2011;111:5404-5433. DOI: 10.1021/cr200024w.

[19] Miao Y, Xue J, Xia F, Yin X, Wu C. Utilization of porous dolomite pellets for the catalytic decomposition of acetic acid. Biomass Bioenerg. 2010;34:1855-1860. DOI: 10.1016/j.biombioe.2010.07.019. 
[20] Outokumpu HSC Chemistry® for Windows, Chemical Reaction and Equilibrium Software. Version 5.1. Outokumpu Research Oy. 2002. Now: Outotec Oyj; http://www.outotec.com/hsc.

[21] Poskropko S, Król D. Biofuels. Part II. Thermogravimetric research of dry decomposition. J Therm Anal Calorim. 2012;109:629-638. DOI: 10.1007/s10973-012-2398-z. 